http://dx.doi.org/10.12795/PH.1990.v05.i01.27

\title{
El personaje del «amigo» en la novela griega antigua: Heliodoro (continuación)*
}

\author{
Máximo Brioso Sánchez
}

Dada la ambiciosa amplitud con que Heliodoro trata los temas y el interés con que profundiza en sus personajes (no en todos por supuesto), no debe sorprendernos que el tipo del «amigo» adquiera en su obra proporciones y complejidades muy novedosas. Tampoco creemos que debe haber dudas sobre el hecho de que, tras la experiencia del desdoblamiento de Aquiles Tacio, Heliodoro ha preferido no retornar al «amigo» único de los inicios del género. Reaparece así el par de «amigos», planteándose de nuevo el problema argumental del reparto de sus papeles a través de la novela y el de la economía de ese reparto. Cnemón, el más caracterizado como «amigo» y como eficaz auxiliar ${ }^{1}$, cubre principalmente los libros I-II y V-VI; Tíamis, que en cambio tiene una función mucho menos estricta como camarada en I, cubre como «amigo» sobre todo los libros VII y VIII, en que, como veremos, su papel de tal se realiza de un modo bastante notable, desde el momento en que, con el claro predominio de sus propios fines como complemento, el sino mismo de los protagonistas termina vaciándolo de funciones. Ante el plan divino Tíamis no podrá sino desaparecer de la escena, al ser su amistad ya progresivamente inútil ${ }^{2}$.

Por otro lado, estos dos «amigos» se ven envueltos en las complicadas relaciones que se crean nuevamente en el grupo, al menos en ciertas ocasiones. Como en Aquiles

* Quede para otra ocasión el estudio de las posibilidades que el personaje del «amigo» pueda ofrecer en los fragmentos novelescos, así como el sacar las conclusiones generales pertinentes.

${ }^{1} \mathrm{La}$ falta de algún leal sirviente equiparable al Sátiro de Aquiles Tacio al lado de la pareja protagonista en Heliodoro obliga a que papeles como los del «amigo» Cnemón y en parte incluso Calasiris deban suplir en ocasiones esa función.

${ }^{2}$ Es un hecho frecuentemente observado la desaparición progresiva de personajes en Heliodoro. Pero éste se limita a desarrollar un aspecto ya presente en los otros novelistas. Suele olvidarse que los personajes secundarios de la novela son eminentemente funcionales: una vez desaparecidas las exigencias de su papel («rival», «agresor», etc.), desaparece también el personaje. 
Tacio, su actuación está muy mediatizada por la existencia de este (o mejor de estos) agregados de personajes y a la vez cada uno de los «amigos» por la del otro. La formidable presencia de Calasiris, sobre todo, oscurece en parte de la obra al menos la de ambos «amigos». Y, por último, es de señalar también que la, muy fuerte, autonomía de éstos igualmente se ve sin embargo disminuida por el hecho de que Heliodoro entrelaza sus propias historias con la principal, aunque por supuesto con tal interdependencia resulta enriquecida la trama global.

Examinaremos en primer lugar los motivos y atributos de Cnemón.

Dada la inversión cronológica con que arranca la novela, si bien la primera aparición de este «amigo» es relativamente temprana en el relato $(I 7,3)$, es en cambio tardía en cuanto a la cronología de los hechos narrados ${ }^{3}$. Gran parte, pues, del argumento, y naturalmente todas las etapas que iremos conociendo por boca de Calasiris, le son ajenas, así como todos los sucesos posteriores a su renuncia a la compañía en el libro VI. La extensión por tanto del papel de Cnemón y de su misma compañia (si se nos permite expresarnos asî) es breve, aunque por el contrario sea muy alto su grado de densidad. Dada también la fuerte concentración cronológica de los hechos que se nos narran directamente, el tiempo real en que Cnemón está en escena es muy escaso, por más que haya sido cubierto con una gran cantidad de información. Cnemón no es sino un «amigo» transitorio, como Menelao. Su encuentro con los protagonistas es fortuito, su disponibilidad es nula o sólo muy relativa, desde el momento en que aparece empeñado en la búsqueda de Tisbe (cf. II 9,4) y su desaparición del relato en VI será un elemento aún más negativo que la de aquél en Aquiles Tacio, puesto que es una verdadera renuncia a su calidad no ya de acompañante, sino de algún modo hasta de auténtico «amigo», por lo que ese pasaje deberá ser analizado con gran atención por la novedad que introduce en el género. Incluso como tal, su compañía, además de iniciarse con un encuentro casual, comenzará no por su amistosa iniciativa, a diferencia de los casos de Hipótoo 4 y Menelao, sino por un mandato de Tíamis ${ }^{5}$, de suerte que no debe sorprendernos que muy poco después (I 26 , 5 s.) la prudente Cariclea no considere oportuno que Cnemón comparta su secreto:

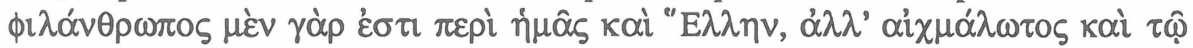

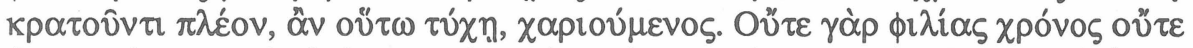

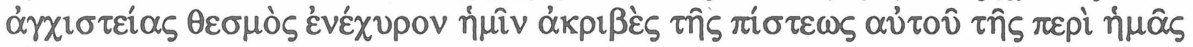

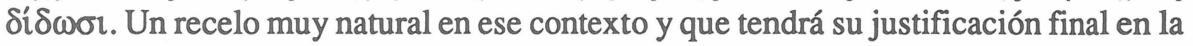
escena de la renuncia. No obstante, ya Teágenes en II 17,1 lo conceptuará de modo

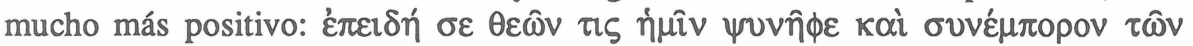

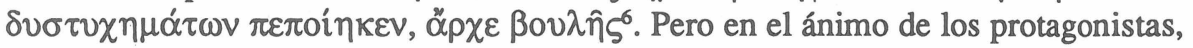

${ }^{3}$ Lo mismo ocurre con Tíamis.

${ }^{4}$ En el caso de éste nos referimos por supuesto a su encuentro con el héroe.

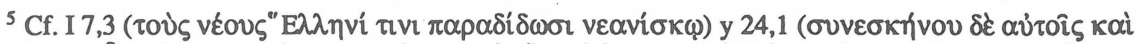

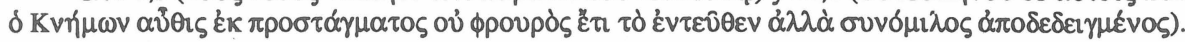
Teágenes interpretará como providencial su aparición en $\Pi 17,1$, que citaremos luego.

${ }^{6}$ Es evidente que, desde el momento en que existe un grupo viajero, el papel de acompañante del «amigo» ha perdido uno de sus principales y casi exclusivos motivos de su esfera de acción. Así, en 
como en el del lector, pesará más sin duda la renuncia citada, que se produce justamente cuando Teágenes parece hallarse en un grave peligro y Calasiris y Cariclea, solos, se aprestan a partir en su busca. Heliodoro ha debido ser muy consciente de la importancia de este momento en la tradición del propio género y lo ha tratado con numerosos y finos detalles sicológicos ${ }^{7}$. Cnemón, dominado por el amor hacia la hija de Nausicles y por tanto por los atractivos de una vida estable y familiar, lamenta tener que tomar la

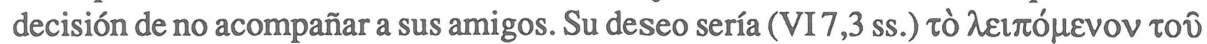

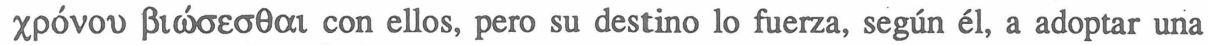

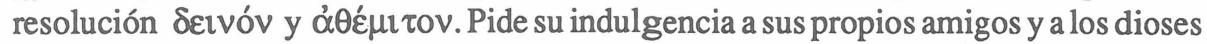

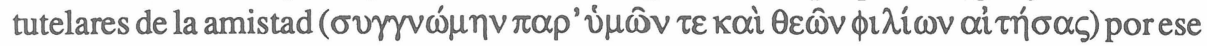
su justificado anhelo de regresar a su patria y a los suyos. Cariclea es la principal destinataria de esta súplica: él estaría con todo dispuesto a acompañarla y mostrarse así

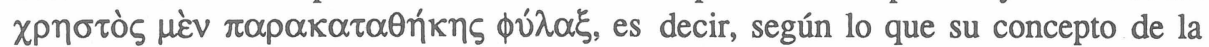
amistad le exige, pero ella ha entendido la más profunda y no expresada razón de estas vacilaciones, el amor, que lo convertiría de modo automático en un acompañante

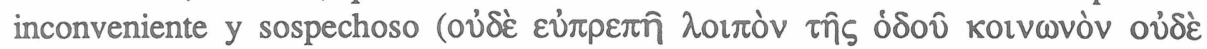

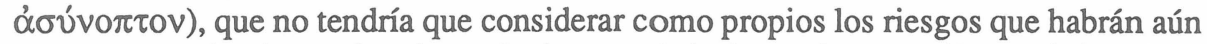

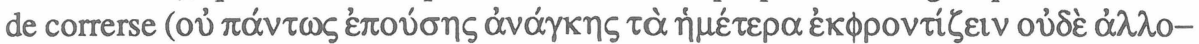

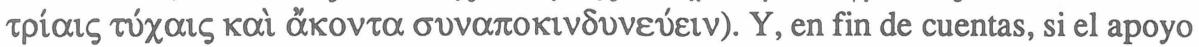

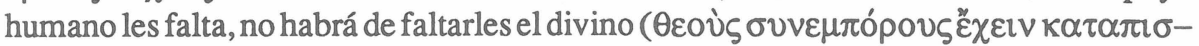
$\tau \varepsilon v ́ o v \tau \varepsilon \zeta)$. Lo que resta es ya sólo el reconocimiento de la deserción, cuando en frase

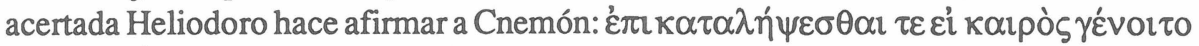
$\pi \lambda \alpha \tau \tau o \mu \varepsilon ́ v o v$ («fingiendo que los alcanzaría después, si había oportunidad de ello»: VI 11,2).

El auxilio del «amigo», pues, y esto es indiscutible en toda la novela y ya tiene antecedentes (sobre todo en Jenofonte), puede ser sustituido por la ayuda de los dioses

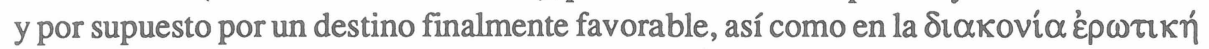
por un personaje como Calasiris. Y más adelante se verá que el socorro de Tíamis no tendrá resultado alguno ante esta competencia divina. Pero nos parece más interesante aún, desde la perspectiva del personaje que estudiamos, el que su renuncia, bajo toda esa dramática retórica, se deba a un motivo tan simple como el haber recuperado su propia vida autónoma y haber perdido consecuentemente su disponibilidad. El motor de la renuncia es un nuevo amor, es decir, el ingrediente que con frecuencia hemos echado de menos en los «amigos» precedentes.

De los restantes motivos algunos pueden en general ser examinados más someramente. Existe en alguna ocasión (II 2,1; cf. también II 3,4) impedimento de suicidio. El consuelo puede adoptar la forma de ciertas atenciones (así, en I 8,4 s., con Teágenes

Heliodoro (III 11,5) los dioses imponen a Calasiris la misión de tomar por compañeros de viaje a los

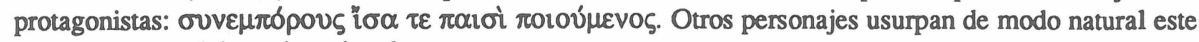
motivo antiguo del «amigo» igualmente.

${ }^{7}$ Un análisis más detallado de este pasaje de la novela puede leerse en un artículo reciente, del que aquí se ofrece sólo un rápido extracto: «Heliodoro VI 5-11 y la crisis del "amigo" en la novela», Habis 18-19, 1.987-1.988, pp. 101-107. 
herido, o con Cariclea en II 6,4) o incluso de familiar reprimenda a la heroína (VI 5,3) o puede dirigirse a otros personajes (a Calasiris en III 4,10 y VI 5,1) o, por inversión, ser recibido (de Calasiris: V 3,3). El estímulo se manifiesta en la forma de capacidad de decisión en I 27 (vd. después sobre este pasaje), pero aparece más bien invertido (cf. sobre todo II 6,2 y 11,3, en boca de Teágenes, aunque éste le pedirá poco después un plan de actuación en 17,1). También Teágenes reanimará al «amigo» en II 6,1, cuando está conmocionado por la muerte de Tisbe. Cnemón aparece como un joven con frecuencia apocado, al que ciertos sucesos desbordan y acobardan. Apenas podrá hablarse respecto a él de sacrificio, como no se puede hablar de otros motivos (testimonio, engaño, sustitución). Su colaboración en sentido estricto es muy precaria, excepto quizás en algunos momentos de la acción en que, como ocurre en la puesta en práctica de su propio plan en II 17,2 ss., los héroes y él mismo llevan a cabo unos actos previamente acordados. El emparejamiento en cambio nos ofrece una más amplia gama de elementos. Cnemón mismo se equipara con los dos protagonistas en diversas ocasiones y por diversos motivos (principalmente las comunes desdichas): en I 8,6 s., II 9,5; 15,1 s.; 17,2; con el héroe solo en II 1,1 (con Calasiris en VI 1), con Cariclea (por contraste) en VI 8,3 ss.; y una forma de emparejamiento son los mutuos juramentos de lealtad de II 18,2. En cambio, en VI 8,3, en una página deliciosa, se contrasta su feliz himeneo y la triste soledad de Cariclea.

El elogio en boca de los héroes es muy parco (cf. II 18,1, por su hábil plan) y, por el contrario, más de una vez Cnemón sufre sus censuras: así, por parte de Teágenes, en II 5,1 y $4 ; 11,3$ y 18,3; y naturalmente los ya citados recelos de Cariclea. Ni la escena de renuncia era propicia a elogio alguno ni en el final de la novela se menciona en absoluto a Cnemón. De un modo semejante, la recompensa brilla por su ausencia. Su boda no se debe precisamente ni mucho menos a una compensación de los héroes por

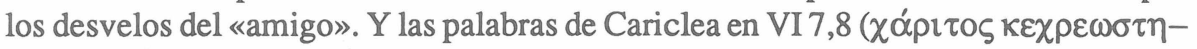

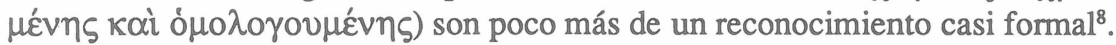

Por lo que se refiere a los atributos, Cnemón es un joven (pero de mayor edad que los protagonistas: cf. II 17,2), ateniense de origen y de «moderada fortuna» familiar ( $\tau \dot{\eta} v$ $\pi \varepsilon p l o v \sigma i \alpha \vee \tau \omega ิ \vee \mu \varepsilon ́ \sigma \omega v: I 9,1)$, aunque su padre fuera miembro del Areópago. Víctima de una vergonzosa calumnia y una acusación injusta que le hacen sufrir la cólera de su padre (I 9 ss.), es en ocasiones ingenuo ${ }^{9}$, pero también prudente e incluso desconfiado en otras (cf. II 11,2; 13,2 s.; 17,2 ss.); observador (II 11,4) y tan lleno de virtud y tan pudoroso sólo de contar su historia (I 10,2). Es ingenioso, como demuestra en el episodio de Termutis (II 19,7), dotado de sentido del humor (cf. II 19,1, por ejemplo), curioso por naturaleza (cf. luego sobre su encuentro con Calasiris), sentimental (cf. I 18,1; 28,4; II

${ }^{8}$ En III 23,3 s., los relatos de Calasiris son, humorísticamente, una recompensa deseada por Cnemón. Se trata de un dato totalmente diferente de lo que hasta aquí hemos entendido por tal motivo.

${ }^{9}$ Se ha exagerado esta nota por parte de algunos comentaristas: cf. por ejemplo, en la edición de Les Belles Lettres $\left(2^{\mathrm{a}}\right)$, I p. XC. La frase «Cnemón, que en ciertos aspectos es un trasunto del héroe principal, hace(n) gala de una ingenuidad sin límites», del traductor de nuestra Biblioteca Clásica Gredos (p. 105 n.) está bastante injustificada. 
3,$2 ; 5,4$, etc.), compasivo (II 14,1), resuelto a veces (II 3,3) y otras apocado y miedoso ${ }^{10}$. Es descrito como $\kappa \alpha \lambda \hat{\varphi}$ por Tisbe $(I I 10,3)$ y sin duda era un mozo tan atractivo a los apasionados ojos de su madrastra como para ser parangonado con Hipólito y Teseo ${ }^{11}$. Aparece como el cautivo de confianza de Tíamis, como intérprete no sólo de lenguas (I 21,3 ) sino de sueños (II 16,5 s.) y conocedor de remedios medicinales (I 8,4 ss.). Cnemón, en fin, posee todo un catálogo de cualidades de todo tipo, algunas de ellas meramente coyunturales, según el autor las va precisando a lo largo del relato. Así, su extremada curiosidad ${ }^{12}$ es claramente un pretexto a la vez que una constante que sirve de contrapunto e incluso alivio a la larga narración de Calasiris: Cnemón se convierte tras el encuentro en un medio para que el anciano nos dé toda su información retrospectiva, pero al tiempo no puede menos de ser un oyente muy interesado por cuanto esa historia afecta, además de sobre todo a sus amigos, también a él mismo (cf. en especial III 24,1 ss.). E igualmente sus miedos, que constituyen un atributo básicamente nuevo en el «amigo», abren posibilidades hacia la figura del acompañante cómico de tanto lucimiento y tan frecuente en las literaturas modernas ${ }^{13}$.

Cnemón es centro y narrador de su propia autobiografia, un episodio no sólo muy extenso y complejo si lo comparamos con las de Hipótoo y Menelao, sino también entrelazado con la historia principal. En él se asume una variante del tema mítico de Hipólito y Fedra y se dan unas consecuencias que, como en el caso de Tíamis según veremos, sustraen al personaje de la típica disponibilidad del «amigo» ${ }^{14}$. Es centro también de algún otro episodio (cf. II 19 ss. y V 2) y centro y narrador de un relato autobiográfico resumido en VI 2,3 s. Sirve de algún modo de enlace entre los protagonistas y Calasiris (cf. sobre todo III 4,7 s.). No puede hablarse respecto a él de vacío en ningún sentido. Realiza una serie de desplazamientos autónomos (desterrado, en I 14,2 s.; a Egipto en II 9,4, con Termutis en II 19 ss.) y se independiza igualmente de los protagonistas a lo largo del episodio de su conocimiento con Calasiris y su historia. Su posible subordinación a los héroes es muy relativa: sólo de modo más claro en su auxilio en el libro I y en la frustrada expedición de comienzos de VI; en cambio, son los protagonistas los que se subordinan explícitamente a él en II 17,1 (cf. ő $\rho \chi \varepsilon$

${ }^{10}$ No es muy valeroso en II 18, al menos en opinión de Teágenes, pero en un momento en que es bastante razonable no serlo. Su actitud ante la ya difunta Tisbe y su supuesta aparición dará lugar a más de una escena humorística (V 2., y sobre todo VI 1,3).

${ }^{11}$ I 10,2 es un pasaje discutido. Estamos convencidos, sin embargo, de que la lectura transmitida es defendible.

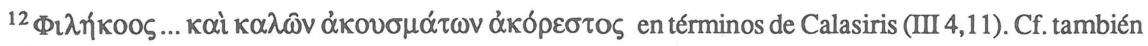
II 17,2, como pretexto para un excursus.

${ }^{13}$ Recordemos ya el caso de Dorcón en Longo y en Aquiles Tacio algún momento de la actuación de Menelao, ya comentado.

${ }^{14}$ Esa no absoluta disponibilidad hace juego sin duda con su posterior deserción en VI. También el nivel erótico de aquella autobiografía puede considerarse un elemento anticipador de la motivación amorosa de la deserción o renuncia. Sin ser aquí el «amigo» un personaje esencialmente erótico (lo que no sería de esperar en Heliodoro), sí parece tener unas dimensiones de sujeto y objeto erótico (de la madrastra y de Tisbe sobre todo) mayores que las de Hipótoo, Clinias y Menelao, pero ello se debe en parte al menos al peso de su autobiografía en el relato. 
ßovגn̂s). En realidad, solamente en el momento de su comentada renuncia se plantea Cnemón el tema de su compañía como hipotéticamente prolongada. Así, en pasajes como III 17 ss., las metas de sus movimientos son muy limitadas y concretas, sobre todo porque los fines de las acciones durante el tiempo en que Cnemón permanece en escena lo son: escapar de un lugar peligroso, buscar a Teágenes, etc. Por otro lado, Cnemón aparece como subordinado a Tíamis (como cautivo de confianza, como «amigo del

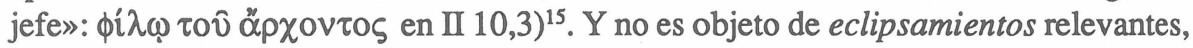
excepto (si queremos interpretarlo así) en el hecho de no ser ni mencionado al final de la novela, como si una cierta justicia poética lo castigara por su deserción. Pero hay aún otro dato de importancia: el de que la vinculación tradicional y estricta entre el «amigo» y el héroe, ya quebrantada en parte en Jenofonte de Efeso y en Aquiles Tacio, se rompe decididamente en Heliodoro. Respondía sin duda a un esquema narrativo demasiado rígido y empobrecedor y cada uno de los novelistas posteriores a Caritón ha tratado de sustituirla por unas relaciones más naturales y flexibles con ambos protagonistas. En el caso de Cnemón estas relaciones prácticamente se desequilibran en favor de Cariclea: el «amigo» será su especial custodio por orden de Tíamis (I 28) y su consolador (I 29,3), llora por sí mismo y por ella (I 28,4 ), la cuidará solícito en II 6,4 , la reprenderá afectuosamente (VI 5,3) y se preguntará angustiado en VI7,5: $\kappa \alpha \tau \alpha \lambda i \pi \omega$ X $\alpha p^{i}$ k $\lambda \varepsilon i \alpha V$

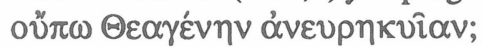

Por lo que se refiere al otro «amigo», si ya Cnemón goza de una gran autonomía, mayor es aún la de Tíamis. Este carece propiamente de lo que hasta aquí se ha entendido por compañía, como un motivo esencial del personaje, siendo más bien él el acompañado por el héroe en la etapa de sus empresas bélicas (inversión). Tampoco está dotado de la disponibilidad tradicional, ya que posee su propia meta: la recuperación de la dignidad sacerdotal usurpada, a la que se subordinan sus principales actuaciones (libro VII). Como víctima de maquinaciones y de exilio, incluida la relativa semejanza entre las viciosas Arsace y Deméneta, se nos representa hasta cierto punto como un doble de Cnemón, con un reparto que no puede interpretarse, creemos, sino como una repetición ampliada y más complicada de los elementos paralelos que encontrábamos ya en el par Clinias-Menelao. Por otra parte, su papel de jefe de una banda de malhechores hace recordar a Hipótoo, de un modo semejante al cual también Tíamis pasa con naturalidad de un status a otro, sin que parezcan existir trabas ni morales ni de otra clase para ello ${ }^{16}$. Tíamis, pues, reitera aspectos de «amigos» ya estudiados. Sufre un destierro, como Menelao; es un bandido, como Hipótoo; como éste también y como Menelao y Cnemón, nace para la amistad con los héroes a raíz de un encuentro fortuito.

En Tíamis desaparecen, al menos como activos, bastantes motivos: consuelo, estímulo, sacrificio, testimonio, engaño, colaboración, sustitución, recompensa ${ }^{17}$ y

${ }^{15}$ La posición de Cnemón en la banda de Tíamis es un tanto particular, aunque más definida que la de Abrócomes en la de Hipótoo.

${ }^{16}$ E. Rohde (Der griechische Roman und seine Vorläufer, Hildesheim $1.960^{4}, \S 448$, p. 477) califica por esta razón a Tíamis de «ein unverständliches Kompositum» entre los dos polos de la vocación sacerdotal y el bandidaje.

${ }^{17} \mathrm{La}$ recuperación del sacerdocio en Menfis no es una recompensa en absoluto tal como se ha entendido este concepto hasta ahora, como no lo es tampoco la boda de Cnemón. 
prácticamente elogio y compañía, por lo que no hay error en afirmar que gran parte de la peculiar impresión que puede causar este cambiante personaje, si se le considera desde la perspectiva del "amigo», se debe a este empobrecimiento de notas bien conocidas. Hay estímulo inverso en el momento en que es a él a quien anima Teágenes ante su inminente lucha con Petosiris (VII 5,3); colaboración también inversa en I 4,2, cuando Tíamis se muestra esperanzado de que Teágenes participe en sus empresas, como de hecho ocurrirá en VII en la campaña contra Menfis ${ }^{18}$. Sus mínimas tentativas de auxilio en instantes críticos resultan frustradas: así, en VIII, en el episodio de la condena de Cariclea y de la prisión, serán la salvación milagrosa de la pira y la actividad de un auxiliar muy secundario como Bagoas los que alejen el peligro y no los intentos generosos de Tíamis. Invertido está igualmente el motivo de la sustitución, desde el momento en que sólo se da una (hipotética) cuando en VII 5,5 Tíamis cree ver en Teágenes un posible sucesor en el mando de sus tropas, al igual que una también hipotética recompensa (ibid.) para Teágenes si el «amigo» logra la victoria (recuérdese

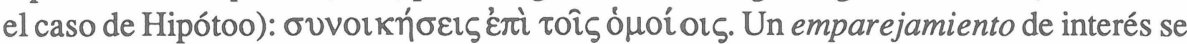
produce (I22,6) al equipararlo Cariclea con ella misma y con Teágenes por su condición de hijo de un sacerdote (lo que se confirmará en el desenlace de la novela) ${ }^{19}$, en tanto que en otro momento en cambio se le define por un claro contraste, en boca también de Cariclea (I 25,5), con Teágenes ${ }^{20}$. Y en cuanto al elogio, sólo cabe oponer a esa citada censura de Cariclea, creíble por ser dicha en privado a Teágenes, la diplomática calificación de «piadoso» con que la joven lo adorna en público (I 21,2$)^{21}$. Es Tíamis, por el contrario, el que elogia a su amada Cariclea en I $21,2$.

Frente a su pobreza en el capítulo de los motivos, Tíamis posee una gran riqueza en el de los atributos, lo que significa que hay una notable distancia entre su actividad como «amigo» típico y su propia personalidad, que domina totalmente sobre aquella.

Según VII 8,3, es sin lugar a dudas de mayor edad que Teágenes e incluso un verdadero adulto ya, lo que nos recuerda a Hipótoo. También recuerda a éste por su papel inicial de jefe de banda, de probada bondad sin embargo, como situación igualmente transitoria y provocada por determinadas circunstancias (cf. I 19,3). En cambio, es, a pesar de su amor por Cariclea, una varón casto por naturaleza (VIII 2,3:

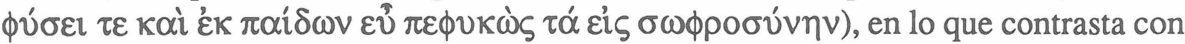
Hipótoo y por supuesto también con los «amigos» de Aquiles Tacio y para lo que podemos dar como causa básica la moralización general impuesta por Heliodoro al sector de sus personajes «positivos» frente al vicio y depravación de los más «negativos». De origen noble, hijo del sacerdote de Menfis que resultará ser Calasiris, caudillo

${ }^{18}$ Una inversión muy importante desde luego. En vez de colaborar el «amigo» sobre todo en la acción típica de la búsqueda de la amada o en todo caso en otras empresas secundarias del héroe, es éste el que apoya el logro de la particular meta del «amigo». Aunque siempre hemos entendido por colaboración un motivo diferenciado de la compañía, es evidente que la inversión de ésta ha arrastrado la de aquélla.

19 Otro emparejamiento, pero éste de la parte del autor: Tíamis y Teágenes como los dos negociadores en VII 3,3.

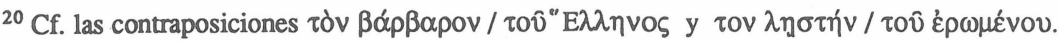

${ }^{21}$ Un elogio en boca de otro personaje: en II 14,2 Tíamis es elogiado por Termutis por su heroísmo. 
en diversas situaciones bélicas, se mueve entre el individualismo egoísta que le hace abandonar a los suyos en plena batalla por su pasión por Cariclea y el comportamiento más heroico (I 28 ss. y VII 5,2); es solícito con sus cautivos (cf. sobre todo I 4,2 s.), a los que admira por su noble porte y su hermoso aspecto (I 4,3), equitativo con sus camaradas y defensor de la justicia (I 19,4 y VIII 3 s.), magnánimo (VII 5,4), deferente con Teágenes por el amor de su supuesta hermana (I 24,2$)$ y sin embargo objeto de los naturales recelos de ésta (VI 9,6) 22 , respetuoso con su padre (VII 7,3), sentimental (I 31,1 ; VII 6,1), etc. Por un tiempo ejerce de «rival», dado su amor hacia Cariclea, pero en este aspecto su relación con Teágenes es muy peculiar, por cuanto éste pasa por hermano de la joven ${ }^{23}$, de suerte que no deja por ello de aparecer como «amigo» de Teágenes ${ }^{24}$. Es centro de episodio en I 18; 28 ss. y VII 2 ss.; lo es de su breve autobiografía en I 19,4 y del complemento biográfico de VII, ya citado; narrador naturalmente en I 19,4, y enlace de algún modo en el libro XII entre los héroes y Arsace y los hechos que se derivan de este contacto. Su biografía, entrelazada con el argumento principal, y sus avatares eróticos (con Cariclea y con Arsace), incluida la muerte de Tisbe por error (I 30,7), lo excluyen del atributo negativo del vacío personal, al igual que su descripción de VII 2,25. El atributo de la subordinación, contrarrestado por la autonomía de Tíamis, está muy alejado de su manifestación originaria en un Policarmo, pero en cierto modo el amable poder que ejerce sobre los héroes en el cautiverio a que los somete se convierte en un paradójico indicio de subordinación («el jefe parecía ser el esclavo», se dice en I 4,3) ${ }^{26}$. Por otra parte, por inversión, en las acciones del inicio de VII es Teágenes el que aparece claramente supeditado a la propia empresa de Tíamis, como segundo de éste en la campaña, y por lo demás la tutela que atribuye Calasiris a su hijo (también a Petosiris) sobre los protagonistas antes de su muerte (VII 11,4) apenas tendrá el menor efecto. Lo relatado en el libro VIII coincide con ciertos eclipsamientos que están entre los más sonados de un personaje novelesco: cf. ya antes, tras su presentación en I 4 ss., en que da paso a su «competidor» Cnemón hasta I 1827, así como luego VII 9 y 12 ss., en que su presencia (aludida ocasionalmente o casi meramente

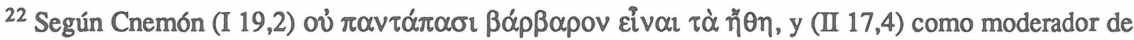

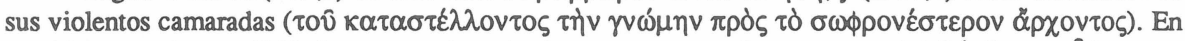

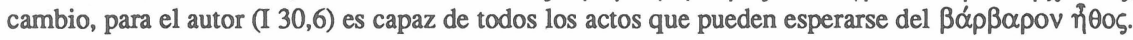

${ }^{23}$ Esta atenuación del papel de «rival» está ligada a su carácter de no «agresor»: el único acto de violencia contra Cariclea es su supuesta muerte (la víctima es Tisbe), ya que por lo demás la razón es el propio amor (I 30, 5-7).

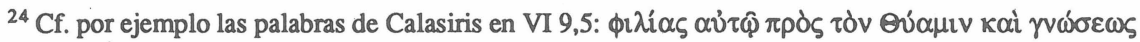
$\pi \rho \circ \pi \alpha \rho \chi 0 v 0 \eta$.

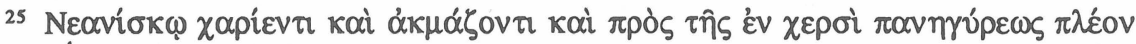

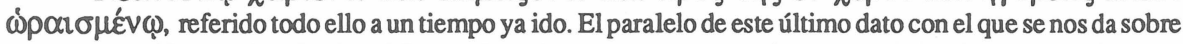
Cnemón en I 10,1 s. salta a la vista. El atuendo de la ocasión acrecienta los deseos de las dos no muy virtuosas señoras.

${ }^{26} \mathrm{Y}$ lo mismo con su amor por Cariclea, a la cual pide cortésmente su consentimiento y a cuyos deseos dilatorios accede (I 21,2 y 23,1 s.).

$27 \mathrm{Su}$ desaparición de escena, con meras menciones esporádicas, entre los libros II y V no es técnicamente un eclipsamiento. 
testimonial) resulta de una extrema ineficacia en medio de los peligros que corren los protagonistas. Es más, estos últimos pasajes de la vida narrativa de Tíamis contrastan por cierto con la (sólo desde el punto de vista del relato) lucida renuncia de Cnemón: Tíamis se apaga más lentamente, y el mismo autor se ve un tanto obligado a justificar esa ineficacia y estos llamativos eclipsamientos con el recurso de sus «deberes» en los funerales de Calarisis (VIII 3,4), aunque por supuesto tal justificación no sea válida para los acontecimientos posteriores, aún más graves para los protagonistas. Justamente, los motivos que Tíamis alega para su preocupación por el destino de éstos son muy reveladores: es otro deber, en este caso impuesto por su padre ${ }^{28}$, amén de la existencia de las razones de la amistad ${ }^{29}$. De suerte que la amabilidad de los primeros contactos, con un Tíamis «rival» pero no «agresor» y que basaba su trato en su propio amor, que diera luego paso al personaje de jefe militar, con Teágenes de fiel acompañante, termina por ser el dócil cumplidor de los mandamientos de su padre y, de paso, un fiel pero ineficaz «amigo» ${ }^{30}$. Y todo ello con el detalle suplementario de que su función de «rival», como ya ocurriera con Hipótoo, se extingue sin más rastro ni recuerdo ${ }^{31}$.

En resumen, Tíamis es, tanto al nivel de «amigo» como al de simple auxiliar, un personaje muy precario. La amistad es en él un hecho secundario. La pérdida de Calasiris será mucho más lamentable para los protagonistas que la de este «amigo», que, al asumir su meta del sacerdocio, puede ser borrado del relato sin problema alguno. Una perspectiva desde la que la comparación con Cnemón ofrece un contraste muy agudo. En cambio, ambos tienen en común el cuidado con que Heliodoro, a diferencia de lo que sucedía en Aquiles Tacio, ha procurado dotarlos de un futuro propio, aunque sea bien diferente por cierto.

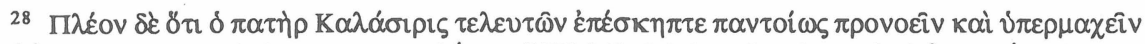

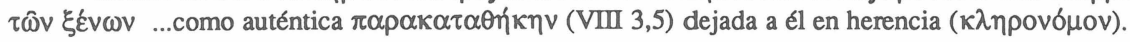

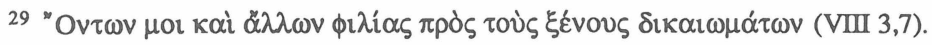

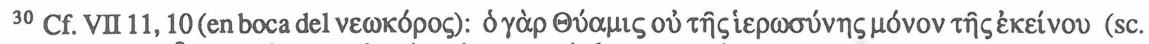

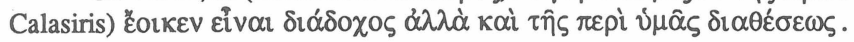

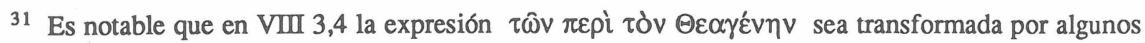
traductores (así en Les Belles Lettres y en la ya citada versión de la editorial Gredos) en un doble «de Teágenes y Cariclea». Es indudable que el autor, consciente o inconscientemente, sigue aquí las primitivas reglas del género: es el héroe masculino el centro de atención del «amigo» y la heroína en todo caso forma parte, desde su perspectiva, de la esfera personal del héroe. 
